\title{
Financial Analysis of Broiler Farm Business in Batu Penjamuran Village Sub District Namorambe (Case Studies on farms Andarias with partnership patterns)
}

\author{
A L Ginting, E Mirwandhono, A H Daulay, Hasnudi, Sayed Umar. \\ Animal Production Program Study, Faculty of Agriculture, University of \\ North Sumatera, Medan 20155, Indonesia \\ E-mail: andreliastaginting @yahoo.com
}

\begin{abstract}
This research was conducted Batu Penjamuran Village Namorambe sub district. The research was conducted in June until December 2016. Research method used was case study at broiler farm Andarias. The location determination in this study was conducted directly on the basis that livestock farming Andarias was a potential farm and has had never been analyzed its business feasibility. This research was used data collection method by observation and direct interview to farmer Andarias. This research showed the income earned by breeder Andarias, in the year 2014 to 2016 sequantially each month as much as Rp. 9.327.568, Rp. 5.508.219, and Rp. 9.023.066.NPV value of $250,784,644$, IRR of $66.58 \%$ and R / C of $1.08 \%$ which could then be declared as a reasonable information. Therefore, the conclusions generated by the researcher was a livestock business by $\mathrm{Mr}$. Andarias expressed could be continued and developed.
\end{abstract}

\section{Introduction}

One of the sectors that has a major contribution to the indonesian economy is the agricultural sector where most of the livelihoods of the indonesian population are in this sector. One of agriculture sub-sectors that is potential to be developed is livestock sector. Livestock development is part of national development which aims to provide animal food in the form of milk meat and eggs of high nutritional value, increase the income of farmers and increase foreign exchange and expand employment opportunities. In the future, it's expected that livestock development can make a real contribution in the nation's economic development.

The government seeks to increase the income of farmers and meat the needs of animal protein communities by utilizing and developing the potential of livesstock areas. The potential of livestock which is worth high selling one of them is broiler chicken. The dvelopment of broiler farms is supported by the strengthening of upstream industries such as 
breeding companies of animal feed companies and veterinary drug companies and downstream industries such as livestock processing companies saragih [1] chiken farming business is devided into 3 categories namely smallholder livestock breeding farms and livestock companies Suharno [2] every company's goal is to maximize profit and maintain the company's sustainability but to achieve that goal the company must be able face many challenges. The cost to the company is the value of the factors of production used to produce the output Boediono [3] reproduction is an expenditure used for a crop or livestock production process in a farming venture Soekartawi [4]. Broiler chiken is the result of cross breeding of a sustainable system so that the good genetic quality. Good genetic quality will emerge maximally as a production performance if the livestock are given a supportive environmental factor such as high quality good feed cage system as well as health care and disease prevention Abidin [5]. Characteristics of broiler chiken seed quality is healty and free from disease comes from a mature parent whose age looks active in bright and lively eyes, have high immunity from parent Fadillah [6]

\section{Materials and Research Methods}

This research was conducted in broiler farm Andarias located in Desa Baru Drying North Sumatera Namorambe district held from june to december 2016

2.1 Research methods

Research method is case study at broiler farm Andarias which is farming people, is located in Desa Batu Drying Namorambe District. The location determination in this studi was conducted direcly on the basis that livestock farming Andarias are potential farm and has never been analyzed business feasibility.

\subsection{Data collection techniques}

This research uses data collection method by observation and direct interview to farmer

\subsection{Data analysis}

Research data to be analyzed descriptively quantitative and further presented using the model of financial analysis thorugh project analysis approach

The financial feasibility formula is

\subsubsection{Net Present Value (NPV)}

$$
\mathrm{NPV}=\Sigma(\mathrm{Bt}-\mathrm{Ct})(\mathrm{DF})
$$

\subsubsection{Revenue Cost Ratio (R/C)}

$$
\mathrm{R} / \mathrm{C} \text { Ratio }=\frac{\text { income }}{\text { cost }}
$$

\subsubsection{Analysis Internal Rate of Return (IRR)}

$$
\mathrm{IRR}=\mathrm{DF} 1+(\mathrm{DF} 2-\mathrm{DF} 1) \frac{N P V 1}{(N P V 1-N P V 2)}
$$

\section{Results and Discussion}

\subsection{Production Cost}

The cost of production is the cost incurred to produce the product by adding up the cost such as DOC, feed, medicine, labor, harvesting and electricity costs. The cost of production each year is constantly changing which is caused by several factors. The annual production cost continues to increase, among others the DOC, where the costs incurred during the three consecutive years are as follows: Rp 212,111,500, Rp 240,625,000 and Rp 297,995,000 


\subsection{DOC}

DOC that is used on farms andarias father in production by PT. Indojaya Agrinusa which later submitted by the company that cooperates with the father andarias. DOC has free pullorum and already get triple vaccine.

Table 1. Price per head DOC

\begin{tabular}{ccc}
\hline year & Price/head DOC & Purchase cost DOC \\
\hline 1 & 5.033 & 212.111 .500 \\
2 & 5.500 & 240.625 .000 \\
3 & 6.250 & 297.995 .000 \\
\hline
\end{tabular}

In table 1 can be seen price DOC every year prices, In the first year with an average of Rp

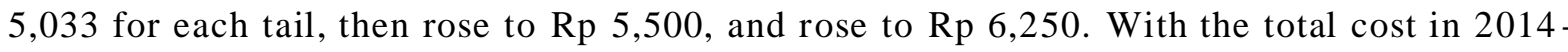
2016 in a row, in the first year the costs incurred for the purchase of DOC amounted to $212,111,500,240,625,000$ and in the third year amounted to 297,995.00.

\subsection{Feed}

Feed given in the form of granules. Farming Enterprises Mr. Andarias uses two types of feed that is feed starter and feed finisher produced by PT. Indojaya Agrinusa. Starter feed is given from age 1-21 days, while finisher feed is given to chickens aged 22 days until harvest. The cost of purchasing feed is the biggest cost that must be paid by Mr. Andarias.

Table 2. Feed prices

\begin{tabular}{ccc}
\hline Year & Feed prices $/ \mathrm{kg}$ & Cost of purchasing feed \\
\hline 1 & 6815 & 804.337 .504 \\
2 & 7225 & 879.490 .000 \\
3 & 7266 & 1.015 .997 .500 \\
\hline
\end{tabular}

In table 2 it can be seen that the average price of feed for each kilogram is increasing every year. In the first year the price of feed for each kilogram of Rp. 6.815, the second year of Rp. 7.225 and in the third year of Rp. 7266 with total cost for the purchase of feed for 3 consecutive years as follows. In the first year of Rp. 804,337,504, Rp. 879,490,000, and Rp. $1,015,997,500$.

3.4 Production result

The result of production is all the products produced in the production activities undertaken by the breeder. In production activities with a partnership pattern, it is possible for farmers to get a bonus if doing good maintenance. By doing a partnership system then the entire production of Mr. Andarias will be purchased by the company that partnered with $\mathrm{Mr}$. Andarias. The selling price for the production is fixed at the beginning by the company without negotiating with the breeder in the form of contract. 
Table 4. Total receips

\begin{tabular}{cccc}
\hline Year & Amount of sales & Bonus & amount \\
\hline 1 & 1.156 .318 .929 & 39.723 .128 & 1.196 .042 .057 \\
2 & 1.243 .274 .698 & 16.090 .310 & 1.259 .365 .008 \\
3 & 1.468 .346 .594 & 29.076 .735 & 1.497 .423 .329 \\
\hline
\end{tabular}

From the table we can see the amount of revenue from the production of livestock in the father andarias continue to increase every year. In the first year of Rp. 1.156.318.929, in the second year to Rp. 1.243.274.698 and increased in the 3rd year to Rp. 1.468.346.594. Sales results continue to increase as influenced by the number of livestock population maintained by the father andarias continue to increase and good maintenance so that the livestock mortality rate is small. In the table also we can see the bonus received by the father andarias, where the bonus received from the bonus market price, bonus depletion (death rate) and bonus FCR.

Bonus market is a bonus that is obtained if the price of livestock in the market is higher than the contract price that has been set in the purchase of the production of the father andarias. The market bonus is $30 \%$ of the difference between the market price and the contract price. Depletion bonus is obtained if the livestock mortality rate during maintenance process does not exceed the death rate set by the company by $5-7 \%$. The FCR bonus is earned if during the maintenance of the father andarias is able to reach the percentage of FCR that has been set by the company of $1.8 \%$. The amount earned varies each year. In the first year of father farm andarias get bonus of Rp. 39,723,128, in the second year earned Rp. 16,090,310, and the third year is Rp. 29,076,735.

3.5 Profit and loss analysis

Profit and loss analysis is to know whether the business is a loss or profit by calculating the difference between the production obtained with the cost of production issued. Profit loss analysis on your farm for the last 3 years can be seen in the table

Table 5. amount of profit/year

\begin{tabular}{cccc}
\hline Year & Production result & Production cost & Profit \\
\hline 1 & 1.196 .042 .057 & 1.084 .111 .239 & 111.930 .818 \\
2 & 1.259 .365 .008 & 1.193 .266 .373 & 66.098 .635 \\
3 & 1.497 .423 .329 & 1.389 .146 .530 & 108.276 .799 \\
\hline
\end{tabular}

In the table can be seen the results of production in three consecutive years have increased. In the first year of farm production of father andarias Rp. 1.196.042.057, in the second year of Rp. 1.259.365.008, and in the third year of Rp. 1.497.423.329. Increased production is also followed by an increase in production costs which each year continues to increase. Production cost for 3 consecutive years as follows. In the first year of production cost of Rp. $1,084,111,239$, in the second year of Rp. 1,193,266,373, and in the third year of Rp. 1.389.146.530. 
3.6 Feasibility analysis

The parameters used for the financial analysis of husbandry farms are using NPV, IRR and R / C calculations. Detailed results of NPV, IRR and R / C calculations for 3 consecutive years can be seen in the table.

Table 10. Recapitulation of the result of the analysis

\begin{tabular}{ccl}
\hline Analysis tools & Result analysis & information \\
\hline NPV & 250.784 .644 & Feasible \\
R/C & $1,08 \%$ & Feasible \\
IRR & $66,58 \%$ & Feasible \\
\hline
\end{tabular}

4. Conclusions

This research shows the income earned by breeder Andarias, in the year 2014 to 2016 sequantially each month is big as Rp. 9.327.568, Rp. 5.508.219, and Rp. 9.023.066.NPV value of $250,784,644$, IRR of $66.58 \%$ and $\mathrm{R} / \mathrm{C}$ of $1.08 \%$ which can then be declared with reasonable information. Therefore, the conclusions generated by the researcher is a livestock business by Mr. Andarias expressed can be continued and developed.

\section{References}

[1] Saragih, B. 2000. Agrbisnis Berbasis Peternakan. Pustaka Wirausaha Muda. Bogor.

[2] Suharno, B. 2000. Kiat Sukses Berbisnis Ayam. PT. Penebar Swadaya. Jakarta.

[3] Boediono. 1980. Ekonomi Mikro. BPFE. Yogyakarta.

[4] Soekartawi, A. Soehardjo, J. Dillon and J.B. Hardaker. 1986. Ilmu Usahatani dan Penelitian untuk Pengembangan Petani Kecil. Universitas Indonesia. Jakarta.

[5] Abidin, Z. 2002. Meningkatkan Produktivitas Ayam Ras Pedaging. Agromedia Pustaka. Jakarta.

[6] Fadillah, R. 2004. Panduan Mengelola Peternakan Ayam Broiler Komersial. Agromedia Pustaka. Jakarta. 